\title{
Diversification of Currency Control Methods in the Digital Economy
}

\author{
Marina Yakovleva*
}

\author{
Ural state University of Economics, Yekaterinburg, Russia \\ *Corresponding author. Email: m_ya123@mail.ru
}

\begin{abstract}
In the article, the author outlined the need to supplement the methods of currency control in the digital economy. The main idea is to introduce a new method - electronic screening. The sequence of actions for implementing this method is shown in the diagrams. The author provides information sources - information resources. The results of the screening form the basis for calculating the risks of illegal currency transactions. The author presented the criteria for determining risks.
\end{abstract}

Keywords: methods of foreign exchange control, foreign exchange transactions, the digital economy, the risk of committing illegal foreign exchange transactions

\section{RELEVANCE OF THE TOPIC}

The methodology of currency control is an important area of research. The correct choice of the control method ensures the effectiveness of the control. The procedure for implementing control methods and recording the results determine the legality of the actions of the Supervisory authorities and the legality of bringing violators to justice. In modern conditions, currency regulation authorities are gradually converting the work of currency control into digital form. This is how currency control moves to the digital economy.

However, it should be borne in mind that unscrupulous participants in foreign trade activities are moving faster to the digital format of relations.

Currently, new types and forms of currency transactions are emerging. Therefore, it is necessary to control not so much currency transactions as payers. This is necessary to prevent illegal currency transactions. To do this, it is necessary to diversify the methods of currency control.

\section{AUTHOR'S GOALS AND OBJECTIVES}

Traditionally, there are three methods of control in science [1]: observation, analysis, and verification.

Usually, observation in science [2] is understood as familiarization with the activities of the object of control without the use of complex techniques. No activity is evaluated as a result of monitoring.

Traditional control methods can be divided into two types of implementation: documentary and actual. As a rule, currency control is a documentary control.

The main goal of the author is to increase the effectiveness of currency control. The author's task is to provide specific suggestions for adding control methods.

\section{DIVERSIFICATION OF METHODS}

To achieve this goal, the author suggests introducing an additional method of currency control-screening. Screening is a comprehensive assessment by currency control authorities and agents of the integrity and solvency of individuals who intend to make currency transactions.

For currency control to be effective, screening is required for preliminary and subsequent control.

From the point of view of screening subjects, the author has identified two types of screening:

- screening of currency control agents (banks);

- screening of currency control authorities (customs and tax inspections).

Bank screening refers to pre-screening. Customs and tax inspection screening should be carried out during subsequent control.

\subsection{Screening of currency control agents.}

Already, banks are partially implementing payer screening. In solving this problem, banks are assisted by a set of Spark software products developed by Interfax. However, the Bank's refusal to conduct a currency transaction only on the basis of suspicions of the payer's bad faith may lead to abuse on the part of banks. In order to avoid abuse by banks, the author suggests introducing a risk system (figure 1). Only a payer with a high level of risk will be refused to perform a currency transaction. The payer with an average risk level will be taken under control. For a payer with a low level of risk, the Bank will be able to conduct currency transactions without hindrance.

The author presents the criteria for risk levels in table 1. 


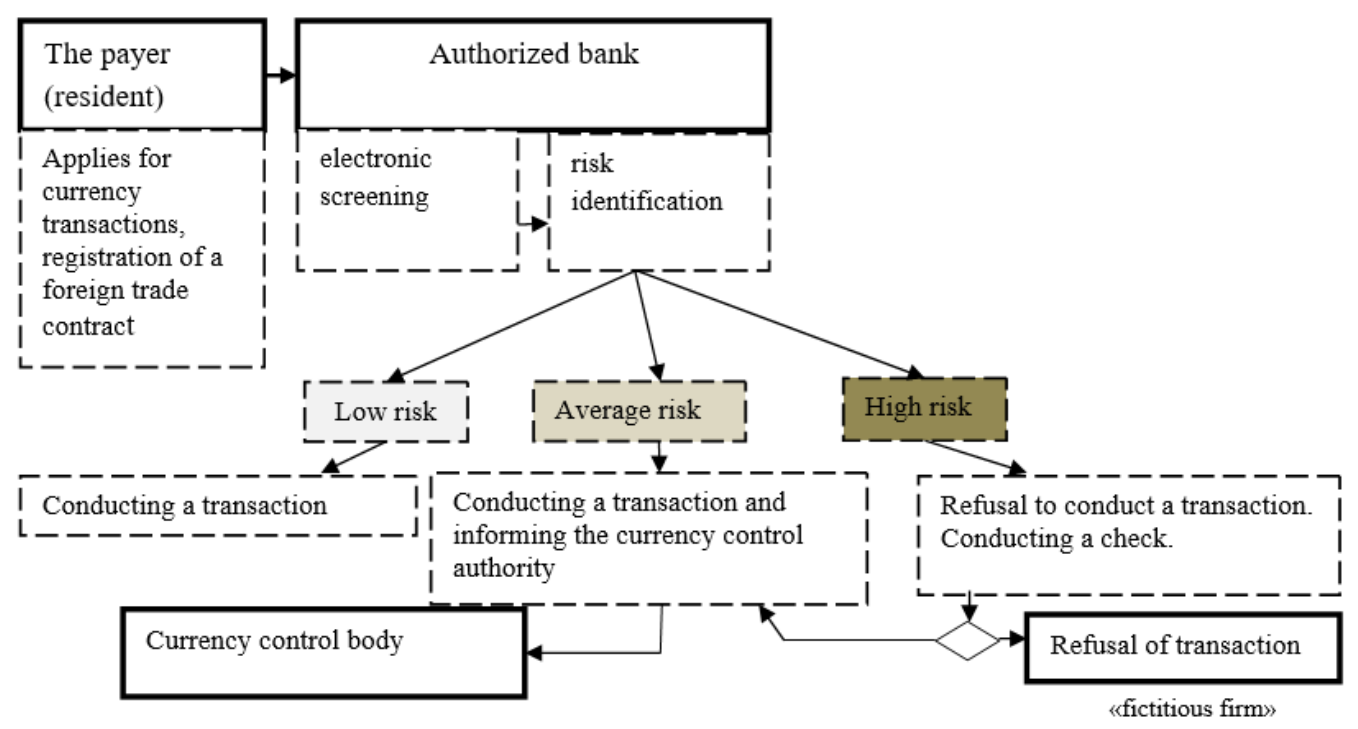

Figure 1 The banking screen

Table 1 Criteria for determining the level of risk of illegal currency transactions

\begin{tabular}{|c|c|c|c|}
\hline Criteria for determining the level of risk & Low risk & Average risk & High risk \\
\hline The validity of the company & $>1$ year & $\begin{array}{l}>3 \text { month but }<1 \\
\text { year }\end{array}$ & $<3$ month \\
\hline Location of the company & $\begin{array}{l}\text { Location at the place } \\
\text { of registration }\end{array}$ & $\begin{array}{l}\text { Absence at the } \\
\text { place of registration }\end{array}$ & $\begin{array}{l}\text { Mass registration } \\
\text { address/ absence at the } \\
\text { registration address }\end{array}$ \\
\hline $\begin{array}{l}\text { The Director's reputation / the reputation of } \\
\text { the founder }\end{array}$ & Good reputation & $\begin{array}{l}\text { Change of Director/ } \\
\text { founder } \\
\text { immediately prior } \\
\text { to performing } \\
\text { operations on a } \\
\text { large scale }\end{array}$ & $\begin{array}{l}\text { Existence of facts of } \\
\text { bringing to } \\
\text { administrative /criminal } \\
\text { responsibility; } \\
\text { the signs of fictitiousness }\end{array}$ \\
\hline Number of employees in the company & $\geq 100$ & $>3$, but $<100$ & $<3$ \\
\hline $\begin{array}{l}\text { Availability of branches and representative } \\
\text { offices }\end{array}$ & Yes & May be & No \\
\hline $\begin{array}{l}\text { Availability of permanent } \\
\text { contractors/business partners }\end{array}$ & Yes & Yes / No & No \\
\hline Presence of signs of transit payments & No & Yes / No & Yes \\
\hline $\begin{array}{l}\text { Compliance of the transaction amount with } \\
\text { the total cash turnover on the company's } \\
\text { accounts }\end{array}$ & Yes & May be & No \\
\hline
\end{tabular}

\subsection{Screening of currency control authorities}

Before starting the audit, the currency controller must establish the integrity of the participant in foreign trade relations. Auto offers to conduct electronic screening using electronic resources (table 2).
This list is not exhaustive and can be supplemented in the course of practical application. The screening scheme is shown in figure 2.

Information obtained from these sources must be formed into a single data Bank. This data will be the basis for calculating risk levels when selecting control objects and for the next analysis. 
Table 2 pre-Verification analysis-electronic screening of currency control authorities

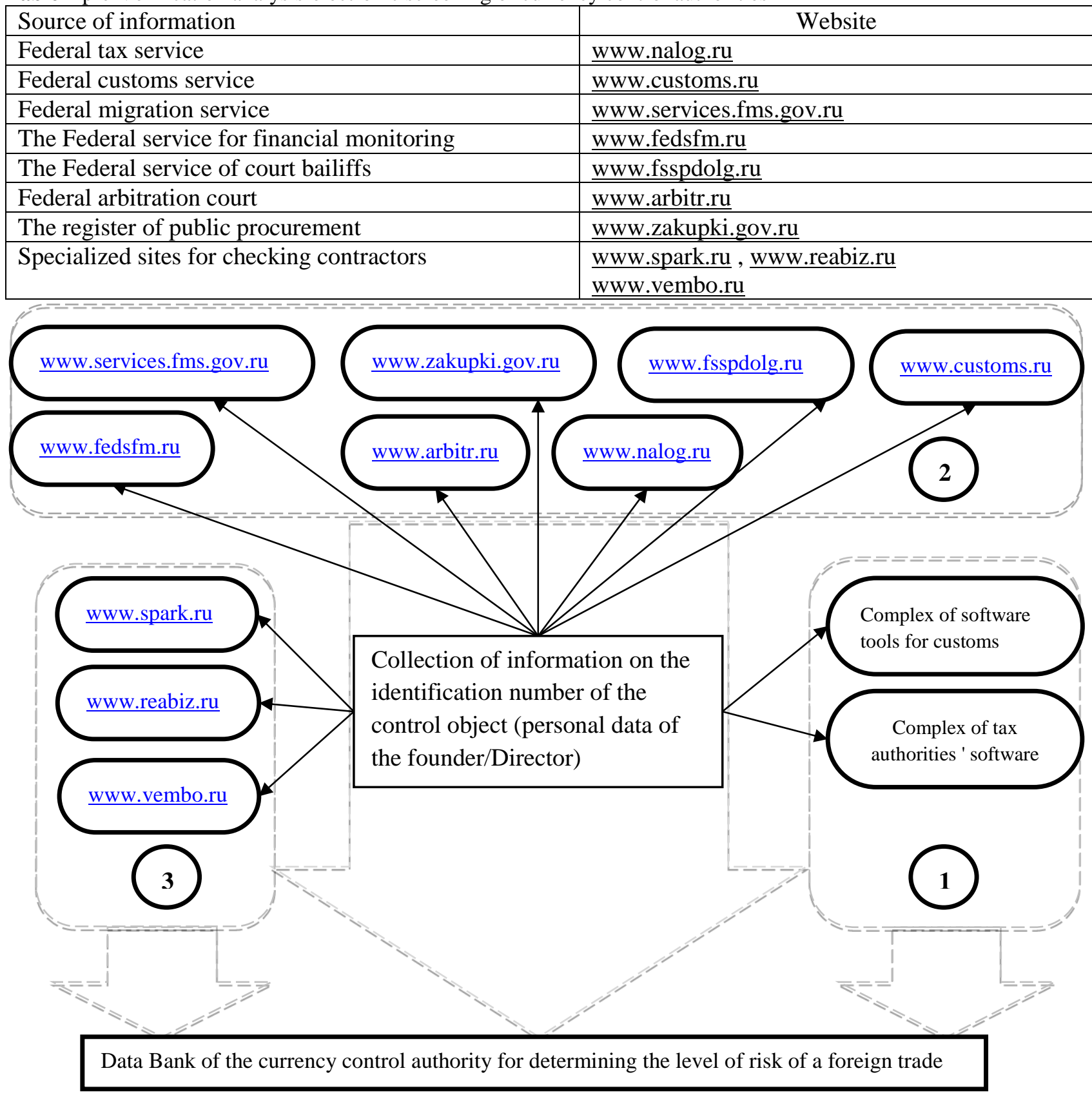

Figure 2 Electronic screening of currency control authorities

\section{REFERENCES}

[1]Khamenushko I. V. Currency control in the Russian Federation Moscow: FBK-PRESS, 2001C. 86-118,

[2] Shokhin S. O., Voronova L. I. Budget and financial control and audit, M.-Finance and statistics, 1997. 